\title{
Copper-Induced Changes in Reproductive Functions: In Vivo and In Vitro Effects
}

\author{
S. ROYCHOUDHURY ${ }^{1}$, S. NATH ${ }^{1}$, P. MASSANYI ${ }^{2,3}$, R. STAWARZ ${ }^{3}$, M. KACANIOVA ${ }^{4}$, \\ A. KOLESAROVA ${ }^{2}$
}

${ }^{1}$ Department of Life Science and Bioinformatics, Assam University, Silchar, India, ${ }^{2}$ Department of Animal Physiology, Faculty of Biotechnology and Food Sciences, Slovak University of Agriculture in Nitra, Slovak Republic, ${ }^{3}$ Institute of Biology, Faculty of Geography and Biology, Pedagogical University of Krakow, Poland, ${ }^{4}$ Department of Microbiology, Faculty of Biotechnology and Food Sciences, Slovak University of Agriculture in Nitra, Slovak Republic

Received April 29, 2015

Accepted July 10, 2015

On-line November 24, 2015

\section{Summary}

The goal of this study is to summarize the current knowledge on the effects of one of the essential metals, copper $(\mathrm{Cu})$ on the reproductive system. The development of past four decades addressing effects of $\mathrm{Cu}$ on reproductive organs is reviewed. The most relevant data obtained from in vivo and in vitro experiments performed on humans and other mammals, including effects of copper nanoparticles (CuNPs) on the reproductive functions are presented. Short term $\mathrm{Cu}$ administration has been found to exert deleterious effect on intracellular organelles of rat ovarian cells in vivo. In vitro administration in porcine ovarian granulosa cells releases insulin-like growth factor (IGF-I), steroid hormone progesterone $\left(\mathrm{P}_{4}\right)$, and induces expression of peptides related to proliferation and apoptosis. Adverse effect of $\mathrm{Cu}$ on male reproductive functions has been indicated by the decrease in spermatozoa parameters such as concentration, viability and motility. Copper nanoparticles are capable of generating oxidative stress in vitro thereby leading to reproductive toxicity. Toxic effect of CuNPs has been evident more in male mice than in females. Even though further investigations are necessary to arrive at a definitive conclusion, $\mathrm{Cu}$ notably influences the reproductive functions by interfering with both male and female reproductive systems and also hampers embryo development in dose-dependent manner.

\section{Key words}

Copper • Effect • Reproductive function - In vivo • In vitro • Nanotoxicity

\section{Corresponding author}

S. Roychoudhury, Department of Life Science and Bioinformatics, Assam University, Silchar 788 011, India. E-mail: shubhadeep1@gmail.com

\section{Introduction}

Copper $(\mathrm{Cu})$ is necessary in maintaining the functioning of living organisms, being an essential trace element (Michaluk and Kochman 2007, Roychoudhury et al. 2008, 2009, Uauy et al. 2008, Yunus et al. 2015). The widespread use of this metal in electronic industry, building materials, water pipes, wood preservatives, transportation sectors, intrauterine contraceptive devices resulted in its adverse effects, including toxicity (CDA 2013, Roychoudhury and Massanyi 2014, Zhang et al. 2012).

Copper is readily absorbed after ingestion, inhalation and dermal exposure (Bentur et al. 1988). Following both acute and chronic ingestion of $\mathrm{Cu}$ compounds significant absorption takes place through the gastrointestinal tract (Cross et al. 1979, Nagaraj et al. 1985, Spitalny et al. 1984). Dietary Cu is absorbed across 
the mucosal membrane in the small intestines, but also to a limited extent in the stomach in mammals (Pena et al. 1999). Active transport mechanisms are believed to be involved at lower dietary levels, while passive diffusion may occur at higher levels (Varada et al. 1993). Most absorbed $\mathrm{Cu}$ is retained within the mucosal cells, bound mainly to metallothionein or glutathione (Tapiero et al. 2003). It is stored primarily in the liver, brain, heart, kidney and muscles. In serum, $\mathrm{Cu}$ is normally about $98 \%$ bound to ceruloplasmin with the remainder in association with albumin. In acute intoxication, when the serum concentration of $\mathrm{Cu}$ rises rapidly, the metal binds to albumin rather than to ceruloplasmin (Piscator 1979). Under normal physiological conditions, approximately $98 \%$ of the $\mathrm{Cu}$ excretion is through the bile and the remaining $2 \%$ is through the urine (Wijmenga and Klomp 2004). The post-Golgi vesicular compartment of the hepatocyte is localized in close vicinity to the biliary canalicular membrane and is thereby involved in the biliary excretion (Langner and Denk 2004). The elimination of $\mathrm{Cu}$ in the urine may be greatly enhanced in the $\mathrm{Cu}$-poisoned patient if the body storage sites are saturated (Walsh et al. 1977). Minimal amounts of $\mathrm{Cu}$ are eliminated in the skin, hair, and sweat (Turnlund et al. 1990). Small amounts of $\mathrm{Cu}$ are secreted daily by salivary, gastric, pancreatic and duodenal excretions. The dietary $\mathrm{Cu}$ biological half-life is reported to be 13 to 33 days, with biliary excretion being the main route of elimination (Barceloux 1999).

Human economic activities, involving the production and usage of $\mathrm{Cu}$ and its compounds, as well as the consumption of materials that contain amounts of $\mathrm{Cu}$, result in its re-distribution in different environmental media. Because it is an essential metal, an adequate supply is necessary for normal metabolism (Georgopoulos et al. 2001). The usual routes by which humans receive toxic exposure to $\mathrm{Cu}$ are through skin or eye contact, as well as by inhalation of powders and dusts (USEPA 1986). In the cases of acute exposure, the inhalation of $\mathrm{Cu}$-containing mists can cause congestion of the mucous membranes in the nose and pharynx, and possibly also ulceration with perforation of the nasal septum (Scheinberg 1983). If the toxicant reaches the gastrointestinal tract, there may be irritation including salivation, nausea, vomiting, gastric pain, hemorrhage, gastritis and diarrhea (Sittig 1985). Ingestion leaves metallic taste in mouth, burning sensation in the throat, nausea, vomiting, epigastric pain, diarrhea, hypotension, hematemesis, melena, hemolytic anemia and gastrointestinal hemorrhage, pallor, oliguria, anuria, jaundice, delirium, coma, hepatic failure, respiratory failure and convulsions are the features of poisoning in the cases of acute exposure. There is centrilobular necrosis and biliary stasis in the liver. In some cases hypotension leading to shock develops, indicating a poor prognosis (Chugh et al. 1975, Cole and Lirenman 1978, Nagaraj et al. 1985, Thirumalaikolundusubramanian et al. 1984). Acute exposure to $\mathrm{Cu}$ salts may cause irritation to the skin (Scheinberg 1983), itching, erythema and an allergic contact dermatitis (Sittig 1985). Metallic $\mathrm{Cu}$ may cause keratinization of the hands and soles of the feet, but not normally dermatitis (Sittig 1985).

Several mechanisms have been proposed to explain $\mathrm{Cu}$-induced cellular toxicity. Copper can exist in both oxidized, cupric $\left(\mathrm{Cu}^{2+}\right)$, or reduced, cuprous $\left(\mathrm{Cu}^{+}\right)$, state. In living cells, $\mathrm{Cu}$ acts as catalyst in the production of superoxide radicals, hydroxyl radicals and hydrogen peroxide via the Haber-Weiss reaction (Bremner 1998, Kadiiska et al. 1993), which can cause oxidative damage and induce adverse effects (Gaetke and Chow 2003). High concentrations of $\mathrm{Cu}$ may cause increased oxidative damage to lipids, proteins, and DNA. Recently, it has been suggested that copper-oxide nanoparticles (CuONPs) are toxic to skin-associated cells and that extracellular signal-regulated kinase (Erk) and p53 may be the key factors regulating the cytotoxicity (Luo et al. 2014). CuONPs also induced oxidative stress and apoptosis in HaCaT human keratinocytes (Alarifi et al. 2013). In another study, human MCF-7 cells were treated with $\mathrm{Cu}^{2+}$ in a dose-response manner and used attenuated total reflection Fourier transform infrared microspectroscopy combined with computational analysis to examine cellular alterations. Cupric ions induced bimodal dose-response effects on cells, while lipids and proteins seemed to be the main cell targets (Llabjani et al. 2014).

Reproductive and developmental effects of $\mathrm{Cu}$ have been well-documented in both in vivo and in vitro experiments (Chattopadhyay and Biswas 2013, Kolesarova et al. 2010, Roychoudhury et al. 2010, 2014). During the last decade a particular rise (from 16-40\%) has been noted in the research relating to reproductive effects of $\mathrm{Cu}$ (Fig. 1A). The goal of this review is to summarize the results of previously performed in vivo and in vitro experiments. The in vivo experiments appear to have attracted more attention from researchers in comparison to in vitro experiments in recent times. Among different targets a large number of in vivo works focused on 
developmental defects (35\%), whereas in vitro research focused more on neuroendocrine effects (25\%). Investigated data is presented into two broad categories: (1) in vivo experiments, and (2) in vitro experiments, which are further subdivided based on the affected targets. The subdivisions mainly include effects of $\mathrm{Cu}$ on neuroendocrine system, ovarian function, spermatozoa, testis, fetal development, and nanotoxicity (Fig. 1B).

A

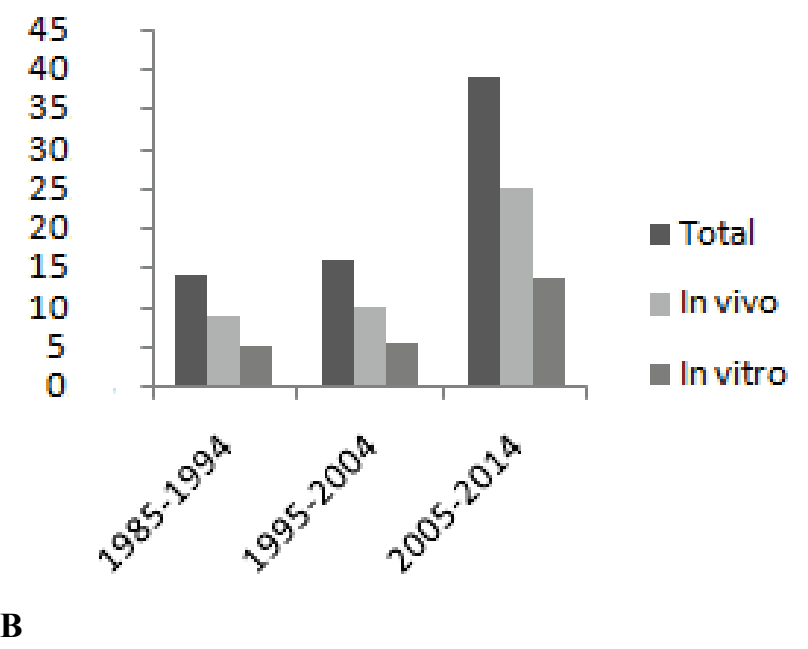

B

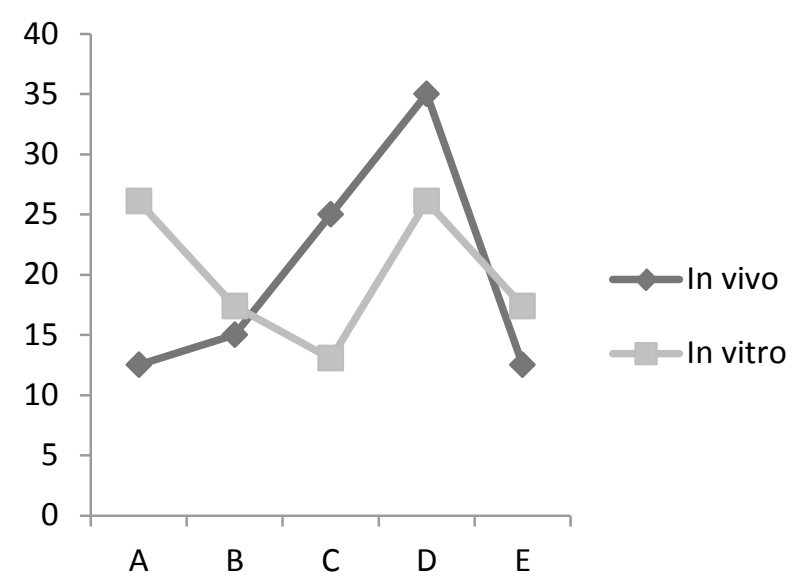

Fig. 1. In vivo and in vitro studies on effects of $\mathrm{Cu}$ on reproductive functions. A: Trend of research in the field of effects of $\mathrm{Cu}$ on reproduction during last three decades and comparison between in vivo and in vitro studies; B: Percentage of studies on effected targets in vivo and in vitro: A - Neuroendocrine effects, $B$ - Effects on ovarian function, C - Effects of spermatozoa and testis, D - Developmental defects, E - Nanotoxicity.

\section{In vivo experiments}

\section{Neuroendocrine effects}

In the development and regulation of reproductive system hypothalamic-pituitary gonadal (HPG) axis plays a critical role (Forgacs et al. 2012).
There are certain classes of compounds which are capable of affecting pituitary function directly by altering the hormone secretion and cellular activity. While some compounds affect pituitary function indirectly by modifying central nervous system (CNS) and gonadal hormone stimulation, many other compounds have both direct and indirect effects (Cooper et al. 1986).

Copper plays an important role in the activity of dopamine $\beta$-monooxygenase by catalyzing hydroxylation of dopamine to noradrenaline, which is an essential neurotransmitter involved in the secretion of gonadotropin releasing hormone $(\mathrm{GnRH})$. Binding of $\mathrm{GnRH}$ with a specific receptor on the gonadotrope cell membrane is responsible for the release of luteinizing hormone (LH) and follicle stimulating hormone (FSH) from the anterior pituitary (Michaluk and Kochman 2007). Complexes of $\mathrm{Cu}$ with $\mathrm{GnRH}$ reportedly evoked the release of FSH more effectively than LH (Kochman et al. 2005), but complex of $\mathrm{Cu}^{2+}$ with luteinizing hormone releasing hormone (LHRH) brought about a high release of LH and even higher release of FSH (Yu et al. 2008). In the presence of $\mathrm{Cu}^{2+}$, secretion of growth hormone by incubated pituitary cells of 32-35 days old pigs was stimulated in vivo (Kochman et al. 2005). Hazum (1983) reported induction of ovulation by $\mathrm{Cu}$ and the reduction in serum LH when reducing agents are injected.

\section{Effects on ovarian function}

As early as 1936, Fevold and colleagues were the first to report that ovulation could be induced by intravenous injection of $\mathrm{Cu}$ salts. It was observed that the number of antral follicles in mice ovaries decreased by $100 \mathrm{mg} / \mathrm{kg}$ copper sulfate $\left(\mathrm{CuSO}_{4}\right)$ administration following 14 days and at a dose of $200 \mathrm{mg} / \mathrm{kg}$ after 35 days showed significantly lower quantities of all follicular classes including primordial, primary, growing, secondary, and antral follicles and also corpus luteum (Babaei et al. 2012). Checking of vaginal smear has been the most widespread method to test ovarian function in laboratory rodents, but certain biochemical parameters from ovarian tissue or blood sample could be more specific functional parameter and histological examination may be performed to check morphological changes (Forgacs et al. 2012). Buffalo-cows were clinically and gynecologically examined and blood samples were collected to study the correlation between $\mathrm{Cu}$ status and ovarian function. Results revealed that $19.12 \%$ of the examined animals showed clear clinical signs of $\mathrm{Cu}$ deficiency (hypocuprosis) and $21.84 \%$ of these hypocupremic buffalo-cows suffered 
from ovarian inactivity and low serum progesterone level, during the luteal phase of the estrous cycle (Ahmed et al. 2009). Short term administration of $\mathrm{Cu}$ (14 days) even with low dose $(100 \mathrm{mg} / \mathrm{kg})$ was found to exert deleterious effects on intracellular organelles of mouse ovarian cells (Babaei et al. 2012). Recently, the most typical ovarian follicle of a rodent bank vole (Myodes glareolus) was presented for the first time. High dose of $\mathrm{Cu}$ was found to exert negative effect on morphological development whereas low dose relatively increased the uterus weight, but $\mathrm{Cu}$ had no effect on the number of follicles (Schramm et al. 2014). Studies on the effect of $\mathrm{Cu}$ on ovarian function have not remained limited to mammals only. Copper exposure has been linked with altered ovarian function in a crustacean, estuarine crab (Chasmagnathus granulata), wherein although 14 days exposure to $0.1 \mathrm{mg} / 1$ of $\mathrm{Cu}$ showed no significant change of the gonadosomatic index the eyestalk ablated exposed females showed significantly lower gonadosomatic index values than the control (Medesani et al. 2004).

\section{Effects on spermatozoa and testis}

The effect of $\mathrm{Cu}$ has been investigated on quality of spermatozoa and testicular histopathology (Sakhaee et al. 2012). The primary functions of the testicles are to produce spermatozoa, androgens, and male sex hormone, testosterone (Forgacs et al. 2012). A significant decrease in spermatozoa concentration, viability and motility indicated the possibility of adverse effect of $\mathrm{Cu}$ on male fertility (Roychoudhury et al. 2008, 2010). Copper was found to play an essential role in spermatogenesis and male infertility in Wistar albino rats (Sakhaee et al. 2012). Copper intake even with low dose $(100 \mathrm{mg} / \mathrm{kg})$ showed adverse effects on testis morphology in male mice $14^{\text {th }}$ day of exposure onwards (Babaei et al. 2012). The role of $\mathrm{Cu}$ in the spermatozoa is unclear, but it appears to be involved in spermatozoa motility and may also act at the pituitary receptors which control the release of LH (Yunus et al. 2015). Fertility is adversely affected by $\mathrm{Cu}$, specifically a decline in male reproductive capacity had been suggested in a number of studies (Roychoudhury et al. 2008, 2010, Sakhaee et al. 2012). In immature male rat a dose of 2000 and $3000 \mu \mathrm{g} / \mathrm{kg}$ body weight for 26 days resulted in reduction of serum testosterone, $\mathrm{FSH}$ and $\mathrm{LH}$ whereas $1000 \mu \mathrm{g} / \mathrm{kg}$ caused rise in their levels (Chattopadhyay et al. 1999). Bank voles, when exposed to 150 and $600 \mathrm{mg} / \mathrm{kg}$ $\mathrm{Cu}$ for 12 weeks showed low sperm count and spermatozoa head abnormalities, while higher dose compromised spermatozoa tail membrane integrity, viability and motility (Schramm et al. 2014).

Among men, symptoms of adverse effect of $\mathrm{Cu}$ usually include prostate enlargement, prostate infections, erectile dysfunction, depression, anxiety, testicular pain and testicular cancer (Badiye et al. 2013). At any stage of cell differentiation the disruption of spermatogenesis may result in the decrease of total sperm count (Sharpe et al. 2003). Moreover, progressive spermatozoa motility is impaired due to the accumulation of metals in the epididymis, prostate, vesicular seminalis or seminal fluid (Hess 1998). Seminal plasma $\mathrm{Cu}$ concentrations found in oligozoospermic, asthenozoospermic and azoospermic groups was significantly higher than normozoospermic group (Eidi et al. 2010).

\section{Developmental effects}

Copper present in either excess or deficient amount during the developmental stage plays an important role. Developmental effects of $\mathrm{Cu}$ relate more to its deficiency rather than toxicity. Development of the CNS was found to be affected by reduced $\mathrm{Cu}$ availability (Danks 1988). Deficiency of $\mathrm{Cu}$ during embryonic and fetal development can result in numerous gross structural and biochemical abnormalities. Evidence for the importance of $\mathrm{Cu}$ for prenatal development arose from studies of enzootic ataxia, a disease in lambs. Neonatal ataxia and brain abnormalities have been reported among $\mathrm{Cu}$ deficient newborn goats, swine, guinea pigs and rats (Keen et al. 1998). Developmental defects were observed in rats, mice, and chickens in response to $\mathrm{Cu}$ deficiency (Hurley and Keen 1979, Opsahl et al. 1984, Phillips et al. 1991, Vulpe 1995). In addition to brain defects, $\mathrm{Cu}$-deficient fetuses and neonates were characterized by connective tissue abnormalities and cardiac hemorrhages in sheep, rats, guinea pigs and mice (Hurley and Keen 1979, Rucker et al. 1998, Tinker and Rucker 1985).

The average intake of $\mathrm{Cu}$ by women during childbearing age is lower than the daily intake for adults, which is $1.5-3.0 \mathrm{mg} \mathrm{Cu}$ (NRC 1989). A correlation between low $\mathrm{Cu}$ in drinking water and the occurrence of neural tube defects was reported (Morton et al. 1976), with an implication that deficiency of $\mathrm{Cu}$ could result in birth defects. It has been found that $\mathrm{Cu}$ increases the incidence of fetal resorptions and induces malformations in the offspring of pregnant hamsters when administered high intravenous doses of $\mathrm{Cu}$ (Ferm and Hanlon 1974). A daily diet supplemented with $>6 \mathrm{mg} \mathrm{Cu} / \mathrm{kg}$ as $\mathrm{CuSO}_{4}$ impaired lactation in female minks (Neovison vison) 
(Lecyk 1980). Increased mortality was observed in the fetuses of pregnant mice fed $104 \mathrm{mg} \mathrm{Cu} / \mathrm{kg}$ /day as $\mathrm{CuSO}_{4}$ during gestation, and developmental abnormalities at $155 \mathrm{mg} \mathrm{Cu} / \mathrm{kg} /$ day (Aulerich et al. 1982).

\section{Nanotoxicity}

Recently, nanoparticles (NPs) have been found to exert adverse effect on reproductive organs, as they are able to penetrate through biological barriers (Singh et al. 2009). Severe toxic symptoms have been observed in male mice suffering more from copper nanoparticles (CuNPs) than females after they were exposed to the same mass of particles (Chen et al. 2006). Copper oxide $(\mathrm{CuO})$ was found to reduce the $\mathrm{GSH}$ content and inhibit the catalase (CAT) and superoxide dimutase (SOD) activities, which caused embryo oxidative damage and changes in the physiology of zebrafish, including hatching failure, shorter body length, and lower reproduction (Liu et al. 2014). Copper NPs were effective in decreasing the reproduction in red worms (Eisenia fetida), too (Alahdadi and Behboudi 2015). Copper oxide NPs significantly reduced the body length of zebrafish. The hatching rates of the embryos exposed to CuONPs decreased with the increasing concentrations of $1 \mathrm{mg} / \mathrm{dm}^{3}$ to $25 \mathrm{mg} / \mathrm{dm}^{3}$ (Liu et al. 2014).

Table 1 summarizes the main in vivo effects of $\mathrm{Cu}$ compounds on reproductive functions.

Table 1. In vivo studies on the effects of Cu compounds on reproductive functions.

\begin{tabular}{|c|c|c|c|}
\hline Test System & Exposure & Effect & References \\
\hline Female mice & $\begin{array}{l}100 \mathrm{mg} / \mathrm{kg} \mathrm{CuSO}_{4} \text { for } 14 \text { days } \\
200 \mathrm{mg} / \mathrm{kg} \mathrm{CuSO}_{4} \text { for } 35 \text { days }\end{array}$ & $\begin{array}{l}\text { Decrease in number of antral follicles } \\
\text { Lower quantities of all follicular } \\
\text { classes including primordial, } \\
\text { primary, growing, secondary, antral } \\
\text { and also corpus luteum }\end{array}$ & Babaei et al. 2012 \\
\hline $\begin{array}{l}\text { C. granulate } \\
\text { (Estuarine crab) }\end{array}$ & $100 \mathrm{mg} / \mathrm{kg} \mathrm{Cu}$ for 14 days & $\begin{array}{l}\mathrm{Cu} \text { produced no significant effect } \\
\text { while eyestalk ablated crabs showed } \\
\text { significantly lower gonadosomatic } \\
\text { index }\end{array}$ & $\begin{array}{l}\text { Medesani et al. } \\
2004\end{array}$ \\
\hline Female mouse & $100 \mathrm{mg} / \mathrm{kg}$ for 14 days & $\begin{array}{l}\text { Deleterious effects on intracellular } \\
\text { organelles of mouse ovarian cell }\end{array}$ & Babaei et al. 2012 \\
\hline Male mice & $100 \mathrm{mg} / \mathrm{kg}$ for 14 days & $\begin{array}{l}\text { Toxic effect from } 14^{\text {th }} \text { day of } \\
\text { exposure on testis }\end{array}$ & Babaei et al. 2012 \\
\hline $\begin{array}{l}\text { Immature male } \\
\text { rats }\end{array}$ & $\begin{array}{l}2000 \text { and } 3000 \mu \mathrm{g} / \mathrm{kg} \text { bw for } \\
26 \text { days }\end{array}$ & $\begin{array}{l}\text { Reduction of serum testosterone, } \\
\text { FSH and LH, whereas } 1000 \mu \mathrm{g} / \mathrm{kg} \\
\text { bw causes rise in their levels }\end{array}$ & $\begin{array}{l}\text { Chattopadhyay et } \\
\text { al. } 1999\end{array}$ \\
\hline Bank vole & $150,600 \mathrm{mg} / \mathrm{kg} \mathrm{Cu}$ for 12 weeks & $\begin{array}{l}\text { Low spermatozoa count and sperm } \\
\text { head abnormality }\end{array}$ & $\begin{array}{l}\text { Schramm et al. } \\
2014\end{array}$ \\
\hline Female mink & $>6 \mathrm{mg} \mathrm{Cu} / \mathrm{kg} /$ day as $\mathrm{CuSO}_{4}$ & Impaired lactation & Lecyk et al. 1980 \\
\hline \multirow[t]{2}{*}{ Pregnant mice } & $104 \mathrm{mg} \mathrm{Cu} / \mathrm{kg} /$ day & Increased mortality rate was observed & $\begin{array}{l}\text { Aulerich et al. } \\
1982\end{array}$ \\
\hline & $155 \mathrm{mg} \mathrm{Cu} / \mathrm{kg} / \mathrm{day}$ & $\begin{array}{l}\text { Developmental abnormalities are } \\
\text { observed }\end{array}$ & \\
\hline Zebrafish & $1 \mathrm{mg} / \mathrm{dm}^{3}$ to $25 \mathrm{mg} / \mathrm{dm}^{3}$ of CuNPs & Decrease in hatching rate of embryos & Liu et al. 2014 \\
\hline
\end{tabular}

\section{In vitro experiments}

\section{Neuroendocrine effects}

Lorenson et al. (1983) investigated the effect of divalent metal ions on in vitro release of $\mathrm{GH}$ and prolactin (PRL) from bovine adenohypophysial secretory granules. Complexes of $\mathrm{Cu}$ with $\mathrm{GnRH}(\mathrm{Cu}-\mathrm{GnRH})$ bind with the $\mathrm{GnRH}$ receptors. The effect of $\mathrm{Cu}-\mathrm{GnRH}$ was 
found to be dose-dependent in porcine pituitary cells to modulate cyclic adenosine monophosphate synthesis and phosphoinositols formation apparently increasing $\mathrm{LH}$ release (Kochman et al. 2005). Copper ions stimulate both basal and GnRH-stimulated LH release from pituitary cells of immature female rats (Hazum 1983). Copper was reported as a potent releaser of $\mathrm{GnRH}$ from isolated hypothalamic granules (Burrows and Barnea 1982), supporting the hypothesis that it influences GnRH neurons and $\mathrm{Cu}$ action only occurs in $\mathrm{GnRH}$ granules.

\section{Effects on ovarian function}

Roychoudhury et al. (2014) for the first time demonstrated the effect of $\mathrm{Cu}$ on IGF-I release by porcine ovarian granulosa cells. Results indicated that the release of insulin like growth factor I (IGF-I) is stimulated by $2 \mu \mathrm{g} / \mathrm{m} \quad \mathrm{CuSO}_{4}$ concentration used, but lower concentrations $\left(0.33-1 \mu \mathrm{g} \mathrm{CuSO}_{4} / \mathrm{ml}\right)$ did not have any influence on IGF-I release (Kolesarova et al. 2010, Roychoudhury et al. 2014). It was observed that $\mathrm{Cu}$ administration in granulosa cells released IGF-I, progesterone $\left(\mathrm{P}_{4}\right)$ and induced expression of peptides related to proliferation and apoptosis. High amounts of $\mathrm{Cu}$ in the follicular fluid and granulosa cells of goat have been detected from small, medium, and large antral atretic follicles, respectively (Bhardwaj and Sharma 2011, Misro et al. 2008). Bhardwaj and Sharma (2011) reported potential use of $\mathrm{Cu}$ as atretic marker and for fertility improvement plans in in vitro studies. The effect of $\mathrm{Cu}$ on porcine ovarian granulosa cells proved to be concentration dependent. A dose of $2 \mu \mathrm{g} / \mathrm{ml} \mathrm{CuSO}_{4}$ was found to enhance the monolayer of porcine ovarian granulosa cells (Kolesarova et al. 2010, Roychoudhury et al. 2014).

\section{Effects on spermatozoa and testis}

Misro et al. (2008) demonstrated the release of $\mathrm{Cu}$ and its effect on functional integrity of human spermatozoa following co-incubation of semen with CuT 380A (intra-uterine device). High release of $\mathrm{Cu}$ from $\mathrm{CuT}$ 380A drastically lowered spermatozoa motility and viability but only marginally affected the acrosome status or nuclear chromatin condensation in short term incubations. Cultured rabbit spermatozoa showed negative influence of high $\mathrm{Cu}$ concentrations in semen, particularly on parameters of spermatozoa motility (Roychoudhury et al. 2008). Decrease of total motility of rabbit spermatozoa was reported within the concentration range of $3.70-4.85 \mu \mathrm{g} / \mathrm{ml} \mathrm{CuSO}_{4}$, beyond which no significant change could be detected (Roychoudhury et al. 2010, Roychoudhury and Massanyi 2008). After $2 \mathrm{~h}$, an increase was noted for both the parameters for evaluation of spermatozoa distance and velocity, i.e. distance curved line and velocity curved line in concentrations 3.63 and $3.57 \mu \mathrm{g} / \mathrm{ml} \mathrm{CuSO}_{4}$, respectively whereas after 24 and $48 \mathrm{~h}$ almost all the spermatozoa including those of control were found to be dead recording no motility at all concentrations. At a concentration of $3.63 \mu \mathrm{g} / \mathrm{ml} \mathrm{CuSO}_{4}$ motility and progressive motility of spermatozoa remained unaltered (Roychoudhury et al. 2010).

\section{Developmental effects}

Fetus stores almost ten times more $\mathrm{Cu}$ than the adult organism per unit of body mass (Michaluk and Kochman 2007). It was shown that $\mathrm{Cu}$ and ceruloplasmin (a Cu-binding protein) concentrations rise significantly during pregnancy, and $\mathrm{Cu}$ is accumulated in brain of fetus (Uauy et al. 2008). Copper is reportedly involved in development of mouse preimplantation embryos in vitro, when exposed to $100 \mathrm{mM}$ concentration for $24 \mathrm{~h}$ at the 1-cell, 2-cell, 4-cell, 6-8-cell, morula and blastocyst stages (Vidal and Hidalgo 1993). It was reported that during in vitro maturation, the optimal embryo development up to the blastocyst stage was partially dependent on the presence of adequate concentration of $\mathrm{Cu}$ (Picco et al. 2012). Percentages of matured oocytes that developed to the blastocyst stage were found to be the highest $(33.2 \pm 1.6 \%)$ in oocytes matured with $6 \mu \mathrm{g} / \mathrm{ml}$ $\mathrm{Cu}$ exposure. In vitro post-implantation development of mouse embryos from Swiss and NMRI strains were investigated for teratogenic potential of $\mathrm{Cu}$. Embryos were cultured in rat serum for $48 \mathrm{~h}$ and supplied concentrations of $\mathrm{CuCl}_{2}$ in culture medium in order to study its direct effects. The embryos from NMRI strain showed failure of closure of neural tube in head region, and significant retardation of embryonic development (Checiu et al. 2008). Development of 2-cell and 8-cell mouse preimplantation embryos to the blastocyst stage was completely inhibited by $\mathrm{Cu}$ concentrations of $13.3 \mu \mathrm{g} / \mathrm{ml}$ and higher (Whittingham 1972).

\section{Nanotoxicity}

Nanoparticles were found to cause pulmonary injury, hepatotoxicity, renal toxicity, immunotoxicity, neurotoxicity, and reversible testis damage in animals (Bai et al. 2010, Bartneck et al. 2012, Chou et al. 2008, Derfus et al. 2004, Lin et al. 2008, Schipper et al. 2008, 
Wu et al. 2011). Recently it was reported that the small size of CuNPs is responsible for its toxic effect (Meng et al. 2007). Copper nanoparticles were found to be capable of generating oxidative stress in vitro (Ahamed et al. 2010, Fahmy and Cormier 2009), which in turns leads to reproductive toxicity. Exposure to CuONPs leads to increase in size of lipid droplets. Copper sulfate salt was more toxic than the CuONPs in freshwater flea Daphnia magna (Tavares et al. 2014).

Table 2 summarizes the main in vitro effects of $\mathrm{Cu}$ compounds on reproductive functions.

Table 2. In vitro studies on the effects of $\mathrm{Cu}$ compounds on reproductive functions.

\begin{tabular}{|c|c|c|c|}
\hline Test System & Exposure & Effect & References \\
\hline $\begin{array}{l}\text { Porcine ovarian } \\
\text { granulosa cells }\end{array}$ & $0.33-1 \mu \mathrm{g} / \mathrm{ml} \mathrm{CuSO}_{4}$ & $\begin{array}{l}2 \mu \mathrm{g} / \mathrm{ml} \text { stimulates IGF-I release but } \\
\text { lower concentration }(0.33-1 \mu \mathrm{g} / \mathrm{ml}) \\
\text { did not have any influence }\end{array}$ & $\begin{array}{l}\text { Kolesarova et al. } \\
\text { 2010, Roychoudhury } \\
\text { et al. } 2014\end{array}$ \\
\hline $\begin{array}{l}\text { Porcine ovarian } \\
\text { granulosa cells }\end{array}$ & $2 \mu \mathrm{g} / \mathrm{ml} \mathrm{CuSO}_{4}$ & $\begin{array}{l}\text { Enhance the monolayer of porcine } \\
\text { granulosa cells }\end{array}$ & $\begin{array}{l}\text { Kolesarova et al. } \\
\text { 2010, Roychoudhury } \\
\text { et al. } 2014\end{array}$ \\
\hline $\begin{array}{l}\text { Human } \\
\text { spermatozoa }\end{array}$ & $\begin{array}{l}\text { Co-incubation of semen with } \\
\text { CuT 380A }\end{array}$ & $\begin{array}{l}\text { Release of } \mathrm{Cu} \text { from } \mathrm{CuT} 380 \mathrm{~A} \text { was } \\
\text { found to be } 9.2 \text { to } 40 \text { times higher } \\
\text { compared to control incubation with } \\
\text { PBS }\end{array}$ & Misro et al. 2008 \\
\hline $\begin{array}{l}\text { Rabbit } \\
\text { spermatozoa }\end{array}$ & $3.70-4.85 \mu \mathrm{g} / \mathrm{ml} \mathrm{CuSO}_{4}$ & $\begin{array}{l}\text { Decrease of total spermatozoa } \\
\text { motility, beyond } 4.85 \text { no significant } \\
\text { change could be detected }\end{array}$ & $\begin{array}{l}\text { Roychoudhury et al. } \\
2010\end{array}$ \\
\hline $\begin{array}{l}\text { Rabbit } \\
\text { spermatozoa }\end{array}$ & $3.63 \mu \mathrm{g} / \mathrm{ml} \mathrm{CuSO}_{4}$ & $\begin{array}{l}\text { Motility and progressive motility } \\
\text { remains unaltered }\end{array}$ & $\begin{array}{l}\text { Roychoudhury et al. } \\
2010\end{array}$ \\
\hline $\begin{array}{l}\text { Mouse } \\
\text { preimplantation } \\
\text { embryo }\end{array}$ & $\begin{array}{l}100 \mu \mathrm{M} \text { for } 24 \mathrm{~h} \text { at } 1 \text {-cell, } 4 \text {-cell, } \\
6-8 \text { cell morula and blastocyst } \\
\text { stage }\end{array}$ & $\mathrm{Cu}$, affect the developmental stages & $\begin{array}{l}\text { Vidal and Hidalgo } \\
1993\end{array}$ \\
\hline $\begin{array}{l}\text { Mouse embryo } \\
\text { (Swiss and NMRI } \\
\text { strain) }\end{array}$ & $\begin{array}{l}9^{\text {th }} \text { day embryo cultured in rat } \\
\text { serum for } 48 \mathrm{~h} \text { and supplied } \\
\mathrm{CuCl}_{2}\end{array}$ & $\begin{array}{l}\text { Embryo from NMRI strain presented } \\
\text { failure of closure of neural tube in } \\
\text { head region of the embryo }\end{array}$ & Checiu et al. 2008 \\
\hline $\begin{array}{l}\text { Mouse embryo } \\
(2-\text { cell and } 8 \text {-cell) }\end{array}$ & $13.3 \mu \mathrm{g} / \mathrm{ml} \mathrm{Cu}$ and greater & $\begin{array}{l}\text { Blastocyst stage was completely } \\
\text { inhibited by } \mathrm{Cu}\end{array}$ & $\begin{array}{l}\text { Whittingham et al. } \\
1972\end{array}$ \\
\hline
\end{tabular}

\section{Conclusions}

The results of previous investigations indicate that the hormonal effects may play an important role in the effects of $\mathrm{Cu}$ on reproductive functions both at the neuroendocrine and gonadal levels in the HPG axis (Cooper et al. 1986, Forgacs et al. 2012). Complexes of $\mathrm{Cu}$ with $\mathrm{GnRH}$ induce the release of FSH and $\mathrm{LH}$ (Cooper et al. 1986). Targets of effects include the neuroendocrine system, spermatozoa, and development of embryos, testicular and ovarian functions. Copper plays an important role in the activity of dopamine $\beta$-monooxygenase, which participates in tyrosine metabolism (Michaluk and Kochman 2007). Adequate amount $\mathrm{Cu}$ is needed during the development of embryo (Danks 1988), the lack of which may bring about serious developmental defects in the offspring and may even result in fetal resorption (Ferm and Hanlon 1974). Copper NPs, at its infancy cause toxicity at levels of regulation due to their small size (Ahamed et al. 2010). They readily cross the biological barrier resulting in reproductive toxicity (Singh et al. 2009). In human $\mathrm{Cu}$ transport, $\mathrm{Cu}$ is shuttled from one protein to another to eventually become loaded on Cu-dependent enzymes (Festa and Thiele 2011, O'Halloran and Culotta 2000). To avoid toxicity of $\mathrm{Cu}^{+}$, the intracellular concentration of $\mathrm{Cu}$ is regulated via 
dedicated proteins that facilitate its uptake, efflux as well as distribution to target $\mathrm{Cu}$-dependent proteins and enzymes (Festa and Thiele 2011, O'Halloran and Culotta 2000, Robinson and Winge 2010). In humans, the 68-residue $\mathrm{Cu}^{+}$chaperone Atoxl picks up $\mathrm{Cu}^{+}$that has entered the cell via CTR1 and delivers the metal to cytoplasmic metal-binding domains in ATP7A and ATP7B (also called Menke's and Wilson disease proteins, respectively), two homologous multidomain P1B-type ATPases located in the trans-Golgi network (Festa and Thiele 2011, O'Halloran and Culotta 2000, Robinson and Winge 2010). During gestation, copper transfer across the placenta increases (McArdle and Erlich 1991). Uptake is through a high affinity carrier, Ctr1. Ctr1 is expressed early in pregnancy, and homozygous mutant embryos die early in gestation (Lee et al. 2001). Once taken up by the placenta, $\mathrm{Cu}$ is bound to one of a series of chaperone proteins, which deliver the metal to its target molecule. In placenta, ATP7A is located in several different cell types, whereas ATP7B is found only in syncytiotrophoblast (Hardman et al. 2004). Intriguingly, protein levels do not appear to change during gestation, which implies that the increase in transfer seen as development progresses (McArdle and
Erlich 1991) is related to localization of the protein. In a study conducted during the first trimester and at term in 216 mothers in Finland, low copper concentrations in placenta were connected to higher birth weights (Kantola et al. 2004). Impaired placental $\mathrm{Cu}$ trafficking has been associated with the development of preeclampsia (Iseminger et al. 2010). Even though further investigations are necessary to arrive at a definitive conclusion, $\mathrm{Cu}$ notably influences reproduction by interfering with both male and female reproductive functions and also hampers embryo development in dosedependent manner.

\section{Conflict of Interest}

There is no conflict of interest.

\section{Acknowledgements}

This work was supported by the Ministry of Education, Science, Research and Sports of the Slovak Republic (1/0022/13, 1/0532/11), Slovak Research and Development Agency of the Slovak Republic (APVV0304-12) and the Department of Biotechnology, Government of India.

\section{References}

AHAMED M, SIDDIQUI MA, AKHTAR MJ, AHMAD I, PANT AB, ALHADLAQ HA: Genotoxic potential of copper oxide nanoparticles in human lung epithelial cells. Biochem Biophys Res Comm 396: 578-583, 2010.

AHMED WM, KHADRAWY HH, HANAFI EM, HAMEED AR, SABRA HA: Effect of copper deficiency on ovarian activity in Egyptian buffalo-cows. World J Zoo 4: 1-8, 2009.

ALAHDADI I, BEHBOUDI F: The effects of $\mathrm{CuO}$ and $\mathrm{ZnO}$ nanoparticles on survival, reproduction, absorption, overweight, and accumulation in Eisenia fetida earthworm tissues in two substrates. Int J Environ Res 9: 35-42, 2015.

ALARIFI S, ALI D, VERMA A, ALAKHTANI S, ALI BA: Cytotoxicity and genotoxicity of copper oxide nanoparticles in human skin keratinocytes cells. Int J Toxicol 32: 296-307, 2013.

AULERICH RJ, RINGER RK, BLEAVINS MR, NAPOLITANO A: Effects of supplemental dietary copper on growth, reproductive performance and kit survival of standard dark mink and the acute toxicity of copper to mink. J Anim Sci 55: 337-343, 1982.

BABAEI H, ROSHANGAR L, SAKHAEE E, ABSHENAS J, KHEIRENDISH R, DEHGHANI R: Ultrastructural and morphometrical changes of mice ovaries following experimentally induced copper poisoning. Iranian Red Cres Med J 14: 558-568, 2012.

BADIYE A, KAPOOR N, KHAJURIA H: Copper toxicity: a comprehensive study. Res J Recent Sci 2: 58-67, 2013.

BAI Y, ZHANG Y, ZHANG J, MU Q, ZHANG W, BUTCH ER, SNYDER SE, YAN B: Repeated administrations of carbon nanotubes in male mice cause reversible testis damage without affecting fertility. Nature Nanotechnol 5: 683-689, 2010.

BARCELOUX DG: Copper. Clin Toxicol 37: 217-230, 1999. 
BARTNECK M, RITZ T, KEUL HA, WAMBACH M, BORNEMANN J, GBURECK U, EHLING J, LAMMERS T, HEYMANN F, GASSLER N: Peptide-functionalized gold nanorods increase liver injury in hepatitis. $A C S$ Nano Lett 6: 8767-8777, 2012.

BENTUR Y, KOREN G, MCGUIGAN M: An unusual skin exposure to copper: Clinical and pharmacokinetic evaluation. Clin Toxicol 26: 371-380, 1988.

BHARDWAJ JK, SHARMA PK: Changes in trace elements during follicular atresia in goat (Capra hircus) ovary. Biol Trace Elem Res 140: 291-298, 2011.

BREMNER I: Manifestations of copper excess. Am J Clin Nutr 67: 1069S-1073S, 1998.

BURROWS H, BARNEA A: Copper stimulates the release of luteinizing hormone releasing hormone from isolated hypothalamic granules. Endocrinology 110: 1456-1458, 1982.

CDA (Copper Development Association): Copper facts. Accessed June 2013 at http://www.copper.org/education/cfacts/c-home.html

CHATTOPADHYAY A, BISWAS N: Testosterone supplemented protection on inhibition of testicular function induced by copper chloride. DHR Int J Biomed Life Sci 4: 212-223, 2013.

CHATTOPADHYAY A, SARKAR M, SENGUPTA R, ROYCHOWDHURY G, BISWAS NM: Antitesticular effect of copper chloride in albino rats. J Toxicol Sci 24: 393-397, 1999.

CHECIU L, CHECIU M, TUDUCE L, ILUT L: Teratogenic effects of copper upon early implantation mouse embryos - in vitro experimental investigation. Annals of West University of Timisoara (Series of Biology) 11: 51-56, 2008.

CHEN Z, MENG H, XING G, CHEN C, ZHAO Y, JI G, WANG T, YUAN H, YE C, ZHAO F, CHAI Z, ZHU C, FANG X, MA B, WAN L: Acute toxicological effects of copper nanoparticles in vivo. Toxicol Lett 163: 109-120, 2006.

CHOU CC, HSIAO HY, HONG QS, CHEN CH, PENG YW, CHEN HW, YANG PC: Single-walled carbon nanotubes can induce pulmonary injury in mouse model. Nano Lett 8: 437-445, 2008.

CHUGH KS, SINGHAL PC, SHARMA BK: Methemoglobinemia in acute copper sulphate poisoning. Ann Int Med 82: 226-227, 1975.

COLE DEC, LIRENMAN DS: Role of albumin-enriched peritoneal dialysis in acute copper poisoning. $J$ Pediatr 92 : 955-957, 1978.

COOPER RL, GOLDMAN JM, REHNBERG GL: Pituitary function following treatment with reproductive toxins. Environ Health Persp 70: 177-184, 1986.

CROSS JD, DALE IM, SMITH H: A suicide by ingestion of a mixture of copper, chromium and arsenic compounds. Forensic Sci Int 13: 25-29, 1979.

DANKS DM: Copper deficiency in humans. Annual Rev Nutr 8: 235-257, 1988.

DERFUS AM, CHAN WCW, BHATIA SN: Probing the cytotoxicity of semiconductor quantum dots. Nano Lett 4: 11-18, 2004.

EIDI M, EIDI A, POUYAN O, SHAHMOHAMMADI P, FAZAELI R, BAHAR M: Seminal plasma levels of copper and its relationship with seminal parameters. Iranian J Reprod Med 8: 60-65, 2010.

FAHMY B, CORMIER SA: Copper oxide nanoparticles induce oxidative stress and cytotoxicity in airway epithelial cells. Toxicol In Vitro 23: 1365-1371, 2009.

FERM VH, HANLON DP: Toxicity of copper salts in hamster embryonic development. Biol Reprod 11: 97-101, 1974.

FESTA RA, THIELE DJ: Copper: an essential metal in biology. Curr Biol 21: R877-R883, 2011.

FEVOLD HL, HISAW FL, GREEP R: Augmentation of the gonad-stimulating action of pituitary extracts by inorganic substances, particularly copper salts. Am J Physiol 117: 68-74, 1936.

FORGACS Z, MASSANYI P, LUKAN N, SOMOSY Z: Reproductive toxicology of nickel-review. J Environ Sci Health A Tox Hazard Subst Environ Eng 47: 1249-1260, 2012.

GAETKE LM, CHOW CK: Copper toxicity, oxidative stress, and antioxidant nutrients. Toxicology 189: 147-163, 2003.

GEORGOPOULOS PG, ROY A, YONONE-LIOY MJ, OPIEKUN RE, LIOY PJ: Copper: Environmental Dynamics and Human Exposure Issues. The International Copper Association - UMDNJ - Robert Wood Johnson Medical School and Rutgers, The State University of New Jersey, 2001, pp 207. 
HARDMAN B, MANUELPILLAI U, WALLACE EM, VAN DE WAASENBURG S, CATER M, MERCER JF, ACKLAND ML: Expression and localization of Menkes and Wilson copper transporting ATPases in human placenta. Placenta 25: 512-517, 2004.

HAZUM E: Copper and thiol regulation of gonadotropin releasing hormone binding and luteinizing hormone release. Biochem Biophys Res Comm 1: 306-312, 1983.

HESS RA: Effects of environmental toxicants on the efferent ducts, epididymis and fertility. J Reprod Fertil Suppl 53: 247-259, 1998.

HURLEY LS, KEEN CL: Teratogenic effects of copper. In: Copper in the Environment. Part II: Health Effects. NRIAGU JO (ed.), John Wiley \& Sons Publishing, New York, 1979, pp 33-56.

ISEMINGER CV, ANDERSON CM, JOHNSON WT: Placenta copper transport proteins in preeclampsia. FASEB J 24: $609.5,2010$.

KADIISKA MB, HANNA PM, JORDAN SJ, MASON RP: Electron spin resonance evidence for free radical generation in copper-treated vitamin E- and selenium-deficient rats: in vivo spin-trapping investigation. Mol Pharmacol 44: 222-227, 1993.

KANTOLA M, PURKUNEN R, KROGER P, TOOMING A, JURAVSKAJA J, PASANEN M, SEPPANEN K, SAARIKOSKI S, VARTIAINEN T: Selenium in pregnancy: is selenium and active defective ion against environmental chemical stress? Environ Res 96: 51-61, 2004.

KEEN CL, URIU-HARE JY, HAWK SN, JANKOWSKI MA, DASTON GP, KWIK-URIBE CL, RUCKER RB: Effect of copper deficiency on prenatal development and pregnancy outcome. Am J Clin Nutr 67 (5 Suppl): 1003S1011S, 1998.

KOCHMAN K, BLITEK A, KACZMAREK M, GAJEWSKA A, SIAWRYS G, COUNIS R, ZIECIK AJ: Different signaling in pig anterior pituitary cells by GnRH and its complexes with copper and nickel. Neuroendocrinol Lett 26: 377-382, 2005.

KOLESAROVA A, CAPCAROVA M, ROYCHOUDHURY S: Metal Induced Ovarian Signaling. First Edition, Slovak University of Agriculture in Nitra, 2010, pp 135.

LAGNER C, DENK H: Wilson disease. Virchows Arch 445: 111-118, 2004.

LECYK M: Toxicity of $\mathrm{CuSO}_{4}$ in mice embryonic development. Zool Pol 28: 101-105, 1980.

LEE J, PROHASKA JR, THIELE DJ: Essential role for mammalian copper transporter Ctr1 in copper homeostasis and embryonic development. Proc Natl Acad Sci USA 98: 6842-6847, 2001.

LIN P, CHEN JW, CHANG LW, WU JP, REDDING L, CHANG H, YEH TK, YANG CS, TSAI MH, WANG HJ: Computational and ultrastructural toxicology of a nanoparticle, Quantum Dot 705, in mice. Environ Sci Technol 42: 6264-6270, 2008.

LIU J, FAN D, WANG L, SHI L, DING J, CHAN YW, SHEN S: Effect of ZnO, CuO, Ag and TiO2 nanoparticles on Daphnia magna and early life stages of Zebrafish Danio rerio. Environ Protect Engg 40: 139-149, 2014.

LLABJANI V, HOTI V, POURAN HM, MARTIN FL, ZHANG H: Bimodal responses of cells to trace elements: insights into their mechanism of action using a bispectroscopy approach. Chemosphere 112: 377-384, 2014.

LORENSON MY, ROBSON DL, JACOBS LS: Divalent cation inhibition of hormone release from isolated adenohypophysial secretory granules. J Biol Chem 258: 8618-8622, 1983.

LUO C, LI Y, YANG L, ZHENG Y, LONG J, JIA J, XIAO S, LIU J: Activation of Erk and p53 regulates copper oxide nanoparticle-induced cytotoxicity in keratinocytes and fibroblasts. Int J Nanomed 9: 4763-4772, 2014.

MCARDLE HJ, ERLICH R. Copper uptake and transfer to the mouse fetus during pregnancy. J Nutr 121: 208-214, 1991.

MEDESANI DA, GRECO LSL, RODRIGUEZ EM: Interference of cadmium and copper with the endocrine control of ovarian growth, in the estuarine crab Chasmagnathus granulata. Aquatic Toxicol 69: 165-174, 2004.

MENG H, CHEN Z, XING G, YANG H, CHEN C, ZHAO F, ZHANG C, WANG Y, ZHAO Y: Ultra high reactivity and grave nanotoxicity of copper nanoparticles. J Radioanalyt Nuclear Chem 272: 595-598, 2007.

MICHALUK A, KOCHMAN K: Involvement of copper in female reproduction. Reprod Biol 7: 193-205, 2007.

MISRO MM, CHAKI SP, CHANDRA M, MAHESWARI M, NANDAN D: Release of copper from CuT380A Co-incubated with semen and its effect on sperm function in vitro. Indian J Physiol Pharmacol 52: 267-273, 2008. 
MORTON MS, ELWOOD PC, ABERNETHY M: Trace elements in water and congenital malformations of the central nervous system in South Wales. British J Prevent Soc Med 30: 36-39, 1976.

NAGARAJ MV, RAO PV, SUSARAIA S: Copper sulphate poisoning, hemolysis and methaemoglobinemia. J Assoc Physicians India 33: 308-309, 1985.

NRC (National Research Council): Recommended Dietary Allowances. $10^{\text {th }}$ edition. Washington, DC, National Academy Press, 1989.

O'HALLORAN TV, CULOTTA VC: Metallochaperones, an intracellular shuttle service for metal ions. J Biol Chem 275: 25057-25060, 2000.

OPSAHL W, ABBOTT U, KENNEY C, RUCKER R: Scoliosis in chickens: responsiveness of severity and incidence to dietary copper. Science 225: 440-442, 1984.

PENA MMO, LEE J, THIELE DJ: A delicate balance: homeostatic control of copper uptake and distribution. $J$ Nutr 129: 1251-1260, 1999.

PHILLIPS M, CAMAKARIS J, DANKS DMA: Comparison of phenotype and copper distribution in blotchy and brindled mutant mice and in nutritionally copper deficient controls. Biol Trace Elem Res 29: 11-29, 1991.

PICCO SJ, ROSA DE, ANCHORDOGUY JP, ANCHORDOGUY JM, SEOANE A, MATTIOLI GA, FURNUS CC: Effects of copper sulphate concentratios during in vitro maturation of bovine oocytes. Theriogenology 77 : 373-381, 2012.

PISCATOR M: Copper. In: Handbook on the Toxicology of Metals. FRIBERG L, NORDBERG GF, VOUK VB (eds), Elsevier Biomedical Press, Amsterdam, 1979, pp 411-420.

RAO MS, ANJANEYULU N: Effect of copper sulphate on molt and reproduction in shrimp Litopenaeus vannamei. Int J Biol Chem 2: 35-41, 2008.

ROBINSON NJ, WINGE DR: Copper metallochaperones. Annu Rev Biochem 79: 537-562, 2010.

ROYCHOUDHURY S, MASSANYI P: In vitro copper inhibition of the rabbit spermatozoa motility. J Environ Sci Health A Tox Hazard Subst Environ Eng 43: 651-656, 2008.

ROYCHOUDHURY S, MASSANYI P: Introduction to Male Reproduction and Toxicity. First Edition, Slovak University of Agriculture in Nitra, 2014, p. 30.

ROYCHOUDHURY S, SLIVKOVA J, BULLA J, MASSANYI P: Copper administration alters fine parameters of spermatozoa motility in vitro. Folia Vet 52: 64-68, 2008.

ROYCHOUDHURY S, ROGOWSKA KA, MASSANYI P, LUKAC N, BULLA J: Estimation of health impact of environmental contaminants: heavy metals and spermatozoa motility in vitro. In: Proceeding of the International Conference on Emerging Technologis on Environmental Science and Engineering. Aligarh Muslim University, Excel India Publishers, New Delhi, 2009, pp 1660-1681.

ROYCHOUDHURY S, MASSANYI P, BULLA J, CHOUDHURY MD, STRAKA L, LUKAC N, FORMICKI G, DANKOVA M, BARDOS L: In vitro copper toxicity on rabbit spermatozoa motility, morphology and cell membrane integrity. J Environ Sci Health A Tox Hazard Subst Environ Eng 45: 1482-1491, 2010.

ROYCHOUDHURY S, BULLA J, SIROTKIN AV, KOLESAROVA A: In vitro changes in porcine ovarian granulosa cells induced by copper. J Environ Sci Health A Tox Hazard Subst Environ Eng 49: 625-633, 2014.

RUCKER RB, KOSONEN T, CLEGG MS: Copper, lysyl oxidase, and extracellular matrix protein cross-linking. American J Clin Nutr 67: 996S-1002S, 1998.

SAKHAEE E, EMADI L, KHEIRANDISH R, AZARI O, ABSHENAS J, AMIRI E: Evaluation of epididymal sperm quality, and histopathological assessment of male reproductive organ, following experimentally induced copper poisoning in male rats. Andrologia 44: 110-116, 2012.

SCHIENBERG HI: Copper, alloys and compounds. In: Encyclopaedia of Occupational Health and Safety. PARMEGGIANI (ed.), International Labour Organization Publications, Geneva, 1983, pp 546-548.

SCHIPPER ML, NAKAYAMA-RATCHFORD N, DAVIS CR, KAM NWS, CHU P, LIU Z, SUN X, DAI H, GAMBHIR SS: A pilot toxicology study of single-walled carbon nanotubes in a small sample of mice. Nature Nanotechnol 3: 216-221, 2008.

SCHRAMM AM, KRUCZEK M, KAPUSTA J: Effect of copper exposure on reproductive ability in the bank vole (Myodes glareolus). Ecotoxicol 23: 1546-1554, 2014. 
SHARPE RM, MCKINNELL C, KIVLIN C, FISHER JS: Proliferation and functional maturation of Sertoli cells, and their relevance to disorders of testis function in adulthood. Reproduction 125: 769-784, 2003.

SINGH N, MANSHIAN B, JENKINS GJ, GRIFFITHS SM, WILLIAMS PM, MAFFEIS TG: NanoGenotoxicology: the DNA damaging potential of engineered nanomaterials. Biomaterials 30: 3891-3914, 2009.

SITTIG M: Handbook of Toxic and Hazardous Chemicals and Carcinogens. SITTIG M (ed.), Park Ridge Noyes Publication, New Jersey, USA, 1985, pp 256-258.

SPITALNY KC, BRONDUM J, VOGT RL, SARGENT HE, KAPPEL S: Drinking-water-induced copper intoxication in a Vermont family. Pediatrics 74: 1103-1106, 1984.

TAPIERO H, TOWNSEND DM, TEW KD: Trace elements in human physiology and pathology. Copper. Biomed Pharmacother 57: 386-398, 2003.

TAVARES KP, CALOTO-OLIVEIRA A, VICENTINI DS, MELEGARI SP, MATIAS WG, BARBOSA S, KUMMROW F: Acute toxicity of copper and chromium oxide nanoparticles to Daphnia similis. Ecotoxicol Environ Contam 9: 43-50, 2014.

THIRUMALAIKOLUNDUSUBRAMANIAN P, CHANDRAMOHAN M, JOHNSON ES: Copper sulphate poisoning. J Indian Med Assoc 82: 6-8, 1984.

TINKER D, RUCKER RB: Role of selected nutrients in synthesis, accumulation, and chemical modification of connective tissue proteins. Physiol Rev 65: 605-657, 1985.

TURNLUND JR, KEEN CL, SMITH RG: Copper status and urinary and salivary copper in young men at three levels of dietary copper. Am J Clin Nutr 51: 658-664, 1990.

UAUY R, MAASS A, ARAYA M: Estimating risk from copper excess in human populations. Amer J Clin Nutr 88: 8675-8615, 2008.

USEPA (United States Environment Protection Agency): Guidance for Reregistration of Pesticide Products Containing Copper Sulfate. Office of Pesticide Programs. Washington D.C., 1986; Fact sheet No. 100.

VARADA KR, HARPER RG, WAPNIR RA: Development of copper intestinal absorption in the rat. Biochem Med Metab Biol 50: 277-283, 1993.

VIDAL F, HIDALGO J: Effect of $\mathrm{Zn}$ and $\mathrm{Cu}$ on preimplantation mouse embryo development in vitro and metallothionein levels. Zygote 1: 225-229, 1993.

VULPE CD, PACKMAN S: Cellular copper transport. Annual Rev Nutr 15: 293-322, 1995.

WALSH FM, CROSSON FJ, BAYLEY M, MCREYNOLDS J, PEARSON BJ: Acute copper intoxication. Am J Dis Child 131: 149-151, 1977.

WHITTINGHAM DG: The effect of copper on pre implantation development in the mouse. Biol Reprod 7: $140,1972$.

WIJMENGA C, KLOMP LW: Molecular regulation of copper excretion in the liver. Proc Nutr Soc 63: 31-39, 2004.

WU J, WANG C, SUN J, XUE Y: Neurotoxicity of silica nanoparticles: Brain localization and dopaminergic neurons damage pathways. ACS Nano Lett 5: 4476-4489, 2011.

YU B, FU WL, LIU PX: Effects of $\mathrm{Cu}^{2+}$ on the growth hormone secretion of pig pituitary cells in culture (in Chinese). Chinese J Appl Physiol 24: 10-13, 2008.

YUNUS EU, MUSTAFA S, MUSTAFA T, BAKI H: Determination of lead, copper and iron in cosmetics, water, soil and food using polyhydroxybutyrate-B-polydimethyl siloxane preconcentration and flame atomic absorption spectroscopy. Anal Lett 48: 1163-1179, 2015.

ZHANG L, YUAN Z, BI J: Estimation of copper in-use stocks in Nanjing, China. J Indust Ecol 16: 191-202, 2012. 